\title{
Muhasebe Ĕgitimi Alan Meslek Yüksekokulu Öğrencilerinin Etik Davranışlarının Tespiti Üzerine Bir Araştırma: Ortaköy MYO Örnĕ̆i
}

\author{
A Study On The Determination Of Ethical Behavior Of Vocational Education \\ Students Took Accounting Education: A Sample Of Ortakoy Vocational School
}

\author{
$\ddot{O} \breve{g r}$. Gör. Mehmet YÜCENURSEN" \\ Doç. Dr. Haluk DUMAN*** \\ Araş. Gör. Yusuf POLAT
}

\begin{abstract}
ÖZ
Küreselleşmenin ve bilgi paylaşımının hızlanması; sadece ülkeler arası sınırların kalkmasına yol açmamış, aynı zamanda ekonomik işbirliklerinin oluşmasına zemin hazırlamıştır. Ekonomik işbirliklerinin artmasıyla gerçeğe uygun, ihtiyaca uygun, karşılaştırılabilir, doğrulanabilir, anlaşılabilir ve zamanında sunulmuş finansal bilgiye duyulan ihtiyaç artmıştır. Muhasebe meslek mensupları tarafindan olușturulan finansal tablolar, iş̧letme içi ve dışı kullanıcılar açısından büyük önem arz etmektedir. Mevcut ve potansiyel yatırımcllar, verecekleri yatırım kararlarını finansal tablolar ışı̆̆ında vermektedirler. Finansal tabloların doğru ve güvenilir olması, muhasebe meslek mensuplarının mesleki etik kurallarına uymasına bağlldır. Muhasebe mesleğindeki etik kurallar, muhasebe meslek mensuplarının uyması gereken ve mesleğin itibarının yükseltilmesini sağlayan mesleki kurallardır. Bu çalışmada Aksaray Üniversitesi Ortaköy MYO'da muhasebe eğitimi gören öğrencilere yönelik olarak hazırlanan bir takım örnek olaylar (senaryo) verilmiş ve verilen cevaplar doğrultusunda ögrencilerin etik davranışları değerlendirilmeye çalışılmıştır.
\end{abstract}

\section{ANAHTAR KELIMELER}

Muhasebe Etiği, Etik Davranışlar, Muhasebe Ĕ̆itimi

\begin{abstract}
Acceleration of the globalization has prepared for the ground not for only lead to removal of borders between countries, but also the formation of economic cooperation. With the increasing economic cooperation, it has increased the need for financial information presented as fair, according to need, comparable, verifiable, understandable and timely. In terms of internal and external users, the financial statements created by the accounting profession has a paramount importance. Existing and prospective investors are giving their investment decisions in the light of financial statements. To be accurate and reliable, the financial statements are based on conforming to professional ethics of the accounting profession. Ethics in the accounting profession are the rules that professional accountants must follow and which are allowing to raise the profession's reputation. In this study, a number of case studies (scenarios) prepared for the students of Aksaray University Ortakoy Vocational School who took accounting education and in accordance with the answers given, the students will be evaluated in terms of ethical behavior.
\end{abstract}

\section{KEYWORDS}

Accounting Ethics, Ethical Behavior, Accounting Education

Makale Gönderim Tarihi: 24/04/2017

Kabul Tarihi: 18/10/2017

***Aksaray Üniversitesi, Ortaköy MYO, yucenursen @ hotmail.com

**A Aksaray Üniversitesi, İktisadi ve İdari Bilimler Fakültesi, İșletme Bölümü, halukduman70@hotmail.com

**** Aksaray Üniversitesi, Sosyal Bilimler Enstitüsü, İşletme ABD, ypolat2384@hotmail.com 


\section{GíRiş}

İşletmelerin muhasebe departmanlarında üretilen finansal bilgilerden yararlanan ve etkilenen çok sayıda karar alıcı taraf bulunmaktadır. Üretilen finansal bilgi sadece işletmeleri değil aynı zamanda işletme ile ilişkili tüm tarafları etkilemektedir. Bu nedenle işletmelerin finansal durumu ve performansı ile ilgili bilgi üreten muhasebe meslek mensuplarının etik ilkelere uygun davranması büyük önem kazanmaktadır.

Enron, Worldcom, Parmalat gibi büyük şirketlerde yaşanan muhasebe skandallarının etik kuralların ihlali ile ilişkili olması, muhasebe mesleğine ve denetime olan güveni büyük ölçüde sarsmıştır (Yardımcıŏlu \& Ada, 2013). Yaşanan bu gelişmeler muhasebe meslek mensupları için etik değerlerin oluşturulması ve muhasebe etik eğitiminin önemini artmıştır (Conroy \& Emerson, 2006).

Muhasebe etiği, Türkiye'de yok denecek kadar az sayıda üniversitenin müfredatında yer almaktadır. Söz konusu müfredatlara dâhil edilen bu derslerin tam anlamıla muhasebe etiği eğitimi olmadığı, diğer dersler ile birlikte verildiği görülmektedir. "Oysa muhasebe etiği kendi başına, diğer disiplinler ile ilişkili ancak bağımsız bir disiplindir." (Özkan, 2014).

Muhasebe etik eğitimi ile ilgili literatürde, muhasebe meslek mensubu ve adaylarına; ahlaki gelişimin kazandırılabileceği (Alam, 1998; Loeb, 1988), diğer insanlara ve topluma karşı ahlaki açıdan sorumlu olma duygusu aşılanabileceği (McPhail, 1999; Otlu, 1999; Armstrong ve diğ., 2003), örnek uygulamalar ile etik ikilemler karşısında başa çıkma yeteneğinin öğretilebileceği (Wyatt, 2004) şeklinde tanımlamalara yer verilmektedir. Loeb'e (1988) göre muhasebe etik eğitiminin amaçlarını aşağıdaki gibi sıralamak mümkündür:

- Muhasebe mesleğinin belirsizlikleriyle başa çıkabilmek,

- Etik açıdan ortaya çıkabilecek sorunları tanımlamak,

- Ahlaki sorunlar ile muhasebe eğitimini ilişkilendirebilmek,

- Ahlaki sorumluluğu yükseltmek,

- Etik ikilemler ile başa çıkabilmek,

- Etik davranışa yol açacak bir ahlaki düzey oluşturmak.

"Muhasebe meslek etiği; muhasebe meslek mensuplarınca gerek faaliyetlerin yürütülmesi sirasında gerekse herhangi bir sebeple mesleki faaliyetin yürütülmediği durum ve dönemlerde, kanunlara uygun işlemlerin yapılması yanında toplumun değer yargılarına da önem verilerek güvenilir bilgilerin topluma sunulması ve müşteriler, toplum, meslektaşlar ve ilgili meslek kuruluşları ile olan ilişkilerde uyulması gereken kurallar bütünüdür." (Daştan, 2009). Bu tanım ışı̆̆ında muhasebe meslek etiği, muhasebe meslek mensubunun kendi kendini kontrolü ve dürüstlüğü ile ilişkilidir. Meslek mensubunun kendi kendini kontrolü ve dürüstlüğü yani etik yargılama eylemi, ahlaki değerleri ve psikolojik yapısı ile yakından ilgilidir (Armstrong ve diğ., 2003).

Literatürde etik karar verme süreci ile ilgili tam bir görüş birliğinin bulunmadığ 1 ve konuyla ilgili birçok model (Trevino, 1986; Harrington, 1997; Thorne, 1998 vb.) ileri sürüldüğü görülmektedir (Seymen \& Bolat, 2007). Ancak en bilinenlerinden bir tanesi ve muhasebe etiği ile ilgili yapılan çalışmalarda çoğunlukla Thorne'un (1998) modelinden ve çalışmalarından (Thorne, 1999; Thorne, 2000; Thorne, 2001) faydalanıldığı (Armstrong ve diğ., 2003; Cohen \& Bennie, 2006; Mintz, 2006) görülmektedir. Bu bağlamda Thorne'un (1998) etik karar almaya ilişkin modeli Şekil 1'de gösterilmektedir. 


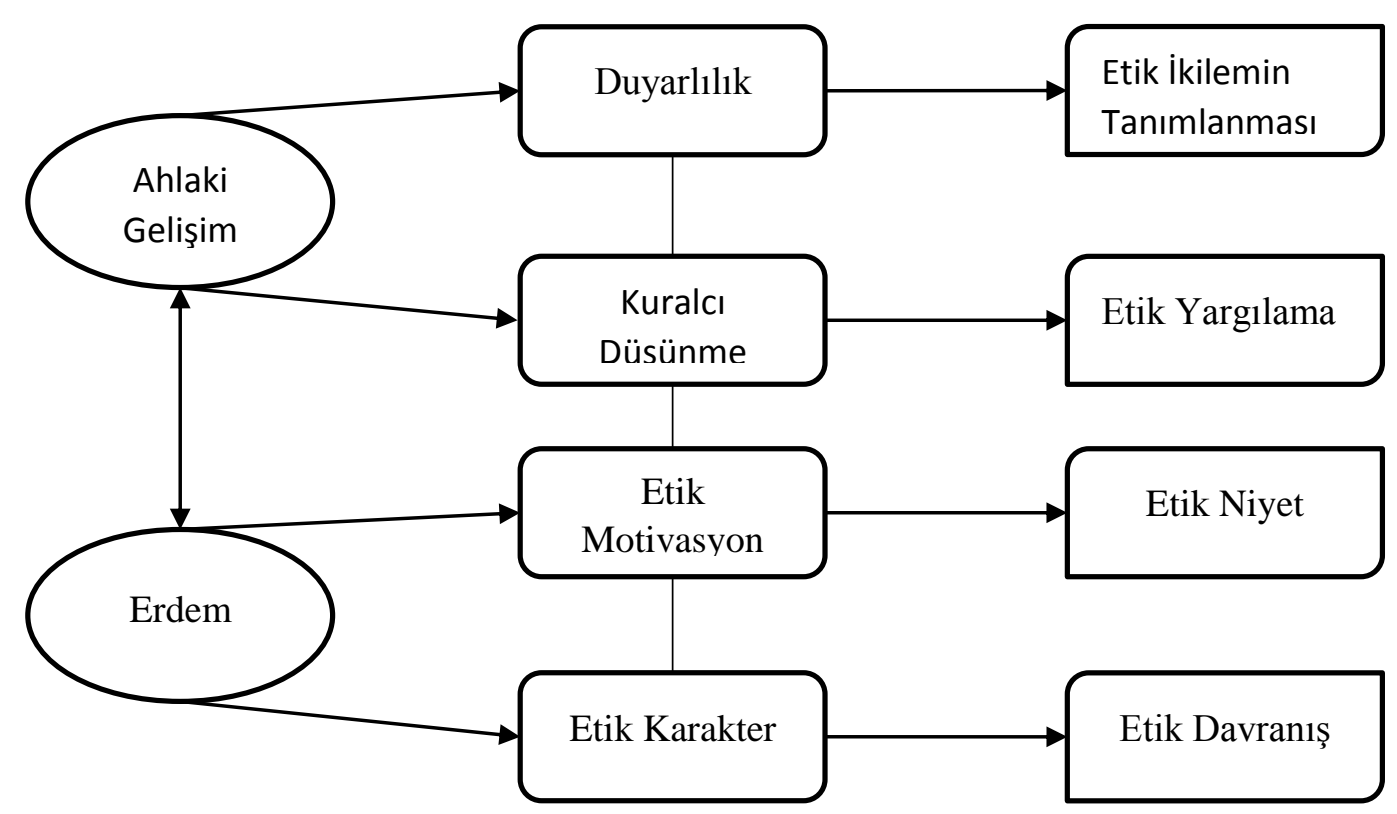

\section{Şekil 1. Etik Karar Verme Modeli}

Kaynak: Thorne, 1998.

Şekil 1'de görüleceği üzere ahlaki erdemin gelişimi etik davranış sergileme açısından önem arz ettiği görülmektedir. Modele göre erdemler, karar vericiyi karakterize etmektedir. Erdemli olmak ve bunları gerçeğe dökmek, karar vericinin etiksel algısını artırmaya dönük eğilimini artırmaktadır. Sonuç olarak Thorne (1998), etiksel davranış için ahlaki gelișim ve erdemin gerekli olduğunu ve bunun sonucu olarak ekonomik olaylar içerisinde kişisel menfaatlerin, işletme ve toplum menfaatleri çatıştığında, sahip olunan bu değerlerin doğru karar alma sürecinde yol gösterici olacağını belirtmiştir.

\section{LITERATÜR TARAMASI}

Cohen ve diğ. (1998), Ameen ve diğ. (1996), Çevik ve Dağdeviren (2015), Kutluk ve Ersoy (2011), Sakarya ve Kara (2010) ve O'Leary ve Radich, (2001); muhasebe meslek mensuplarını etik dışı davranışlara yönlendiren faktörlere yönelik bir çalışma yürütmüşler ve erkek meslek mensuplarının kadın meslek mensuplarına göre daha fazla etik dışı davranışlara yöneldiğini tespit etmişlerdir. Benzer bir çalışmada Aymankuy ve Sarığlan (2015), en önemli araştırma sonucu olarak muhasebe meslek mensuplarının yasal boşlukları mükelleflerin lehine yorumlamalarını göstermiş ve bu durumu mesleki etik ile bağdaştıramamıştır. Meslek mensuplarının, mükellefin menafaatine yönelik davranışları yasa koyucunun bilerek ve isteyerek düzenleme yapmadığ 1 istisna durumlar olabileceğini ve mükellefini koruma amaçlı olduğu için etik olarak kabul etmemek doğru tez olmayabilir. Çünkü vergi literatüründe bu davranışın karşıllı̆ı vergiden kaçınma olarak ifade edilir; bu doğru bir davranıştır. Doğru olmayan; başka bir ifade ile etik olmayan davranış ise "vergi kaçırma" olarak ifade edilebilir.

Daştan (2009) ise muhasebe etik eğimini, Türkiye ve dünyada yaşanan gelişmeler çerçevesinde değerlendirerek üniversitelerin eğitim müfredatına muhasebe etik eğitiminin dâhil edilmesinin esaslarına yönelik önerilerde bulunmuştur. Sonuç olarak, etik konuların mevcut derslerin içerisinde sunulması veya ayrı bir ders olarak verilmesi gerekliliğini vurgulamıştır. Bu bulguları destekler nitelikte bir çalışmayı da Klimek ve Wenell (2011) yürütmüşler ve lisans eğitiminde haftalık 3 saat muhasebe etiği dersi verilmesini önermişlerdir.

Bezirci ve Bayraktar (2015), dört kutsal kitap çerçevesinde muhasebe meslek mensuplarında etik eğitimini inceledikleri çalışmalarında, herhangi bir din merkezli olmayan "etik enstitüleri”" açılmasını ve burada yetiştirilen akademisyenler ile "etik merkezleri" nde muhasebe meslek mensubu adaylarının belli bir terbiye ve usulden geçirildikten sonra mesleğe kabul edilmesi gerektiğini belirtmiş̧lerdir. 
Ağyar ve diğ. (2012), muhasebe meslek mensubu adayı olan muhasebe bölümü öğrencilerinin meslek etiğine bakış açılarını incelemişlerdir. Çalışma sonucunda meslek etiği ile ilgili ders alan öğrencilerin, almayan öğrencilere göre daha etiksel yargılarda bulunduğu gözlemlenmiştir.

Muhasebe etik eğitimine yeni bir yaklaşım önerisi getiren Mahdavikhou ve Khotanlou (2012), İslamın benimsediği etik kurallarının muhasebe eğitimi müfredatına konması gerektiğini belirtmişlerdir.

Bilen ve Yılmaz (2014) ve Meymandi ve diğ. (2015) ise muhasebe mesleğinde etik çalışmalarına yönelik düzenlemeleri konu aldıkları çalışmalarında, muhasebecilerin topluma karşı olan sorumluluklarının diğer mesleklere oranla daha fazla olduğunu ve yapılan çeşitli etik düzenlemelerinin gerekliliğini ortaya koymuşlardır.

Bitlisli ve Dinç (2015), yaptıkları çalışmalarında muhasebe meslek mensuplarının makyavelist kişilik eğilimleri düzeyi ile etiksel karar verme davranışları arasında orta düzeyde bir ilişki olduğu saptamışlardır. Ayrıca çalışmada, muhasebe meslek mensuplarının demografik özellikleri ile etiksel karar verme davranışı arasında önemli düzeyde farklılıklar tespit edilememiştir. Bu bulgular, Elias ve Farag'in (2011) çalışmalarında ulaştı̆̆ sonuçları destekler niteliktedir.

Büyükyılmaz ve Gürkan (2014), mesleki tükenmişliğin muhasebe meslek mensuplarının etik tutumları üzerindeki etkisini konu aldıkları çalışmalarında, tüm boyutlarda mesleki tükenmişlik seviyesindeki azalmanın, muhasebe meslek mensuplarını idealist etik tutumuna yaklaştırdığına ilişkin ters yönlü bir ilişki tespit etmişlerdir. Bu durum mesleğin stresli olması, sürekli mevzuat güncellemeleri ile hayat boyu öğrenme felsefesini gerektirmesi ile yakından ilgilidir. Çalışmaya göre ekonomik olarak hayat standardı yükseldiğinde bu durumun mesleki tükenmişliğin yanında etik davranışları benimseme seviyesini yükselttiği söylenebilir.

Kurnaz ve Gümüş (2010), muhasebe bölümü öğrencilerinin etik dışı davranışlarına ilişkin algılarını incelemişler ve öğrencilerin büyük bir kısmının etik dışı davranışları tasvip etmediklerini saptamışlardır. Ayrıca çalışmada üst sınıftaki öğrencilerin alt sınıftaki öğrencilere göre etik hassasiyetinin fazla olduğu belirtilmiştir.

Daştan ve diğ. (2015), muhasebe meslek mensuplarının etik ikilem ve etik karar alma konularında farkındalık düzeylerini değerlendirmek amacıyla yürüttükleri çalışmada, meslek mensuplarının cinsiyetleri, eğitim düzeyleri ve deneyimleri açısından etik ikilem ve etik karar alma konularında farkındalık düzeylerinin farklı olduğu, unvan açısından farklı olmadığı bulgular arasında yer almıştır.

Alkan (2015), önlisans öğrencilerine yönelik yaptığı çalışmasında, bayan öğrencilerin erkek öğrencilere göre etik değerlerinin daha yüksek olduğunu ve ayrıca gelir düzeyinin de etik algısı üzerinde bir farklılığa neden olduğunu tespit etmiştir.

Yıldız (2010), Kayseri ilinde muhasebe meslek mensupları üzerinde yaptığı çalışmasında, meslek mensuplarının etik konusuna önem verdiğini ve etik eğitiminin gerekliliğine inandıklarını saptamıştır. Meslek mensuplarını etik dışı davranışlara iten nedenler ise mali denetim yetersizliği, kamudaki kayırmalar, kayıt dışı ekonomi, ekonomik istikrarsızlık ve meslek mensupları arasındaki politik ve siyasi görüş farklılıkları olarak belirlenmiştir. Çalışmada öneri olarak lisans düzeyinde etik eğitiminin verilmesi önerilmiştir. Benzer bir çalışmayı da Fidan ve Subaşı (2014) yürütmüş ve bu çalışmada da etik eğitiminin yetersiz olduğuna dikkat çekilmiştir. Ayrıca mesleki etik kurallarına aykırı hareket ettiren nedenlerin başında "müşteri kaybetmemek düşüncesi” olduğu saptanmıştır.

Meslek mensuplarını etik dışı davranışlara iten sebeplerin başında "müşteriyi kaybetmemek" olduğunu saptayan bir diğer çalışma ise Kaya ve Yanık (2011) tarafından yürütülmüş ve mükelleflerin vergi matrahının belirlenmesi için hizmet talep ettikleri, bu durumun ise müşteri kaybı endişeşine yol açtığı saptanmıştır.

Akın ve Özdaşlı (2014), yaptıkları çalışmada meslek mensuplarının ekonomik kaygılara sahip olduğunu, bu yüzden etik olmayan davranışlara yöneldiklerini tespit etmiştir.

Allen (2005), Balsarı ve diğ. (2014) ve Şahin ve Dağlı (2014) ise meslek mensuplarının etik hakkındaki algılarına yönelik yürüttükleri çalışmada, meslek mensupları etik kurallardan sapma nedenlerinden birini eğitim yetersizliği olarak tanımlamışlar ve etik davranışlar sergilemek için gayreti müşterinin de göstermesi gerektiğini belirtmişlerdir. Benzer bir çalışmada Sivas ilinde Kısakürek ve Alpan (2010) tarafından gerçekleştirilmiştir. Çalışmada farklı bir bulgu olarak "AB uyum sürecinin meslek etiğinin gelişmesine katkı sağlayacağı" fikri meslek mensupları tarafından benimsenmiştir.

Ergün ve Gül (2005) ve Yılmaz ve diğ. (2015) ise etik kuralların meslek mensuplarınca algılanışı üzerine yürüttükleri çalışmalarda meslek mensuplarının önemli bir kısmının meslek etik kuralları hakkında bilgi eksikliği içinde olduklarını saptamışlardır. 
Subaş1 ve Fidan (2015) ise muhasebe meslek mensubu adaylarının etik eğitimi hakkındaki görüşlerini ele aldıkları araştırmalarında adayların etik eğitiminin daha çok gerçek vaka çalışmaları şeklinde işlenmesini istediklerini tespit etmişlerdir. Bu bulgular, Allen (2005) ve Balsarı ve diğerlerinin (2014) çalışmalarını destekler niteliktedir.

Yalçın (2011) ise hem muhasebe meslek mensupları hem de işletmelerin etik konusunda tutumları üzerine bir çalışma yürütmüş ve genel olarak TÜRMOB etik yönetmeliği ile getirilen düzenlemeleri benimsedikleri sonucuna ulaşmıştır.

Dinç ve Tunçer (2015) ise vergi müfettişlerinin, muhasebe meslek mensuplarının etik duyarlılıklarına ilişkin algısını incelemişlerdir. Çalışma sonucunda vergi müfettişlerinin, muhasebe meslek mensuplarının etik ilkelere uymaları konusunda oldukça karamsar bir bakış açısına sahip oldukları ortaya konulmuştur. Ancak Sakarya ilinde Hacıhasanoğlu (2013) tarafından gerçekleştirilen çalışmaya göre muhasebe meslek mensupları etik değerlere uygun hareket etmektedir.

\section{UYGULAMA}

\section{Kapsam Ve Yöntem}

Araştırma Aksaray Üniversitesi (ASÜ) Ortaköy Meslek Yüksekokulu (OMYO) Bankacılık ve Sigortacılık, İşletme Yönetimi, Maliye, Muhasebe ve Vergi Uygulamaları bölümlerinde öğrenim gören Genel Muhasebe dersi almış 1. ve 2. sınıf normal ve ikinci öğretim öğrencilerinin kapsamaktadır.

Araştırmada veri toplama aracı olarak, öğrencilerin etik davranışlarla ilgili olarak değerlendirecekleri altı senaryo içeren bir form kullanılmışıı. Form iki kısımdan oluşmaktadır. Birinci kısımda öğrencilerin demografik özellikleri, ikinci kısımda ise senaryolar yer almaktadır. Söz konusu bu formdaki senaryolar; O'Leary ve Radich (2001) tarafından etik davranışları ölçmek için hazırlanan senaryolardan elde ederek Türkçe'ye çeviren, uygulamasını gerçekleştirerek geçerlilik ve güvenirliğini sağlayan Utku'nun (2009) çalışmasından alınmıştır. Ayrıca anketin kendi içinde güvenirliği Cronbach Alfa yöntemi ile test edilmiş ve aşağıdaki tabloda gösterilmiştir.

\begin{tabular}{ll}
\hline \multicolumn{2}{c}{ Tablo 1. Güvenirlik Katsayısı } \\
\hline Anket Sayısı & 335 \\
\hline Senaryo Sayısı & 6 \\
\hline Alfa & 0.817 \\
\hline
\end{tabular}

Anketlerin tamamına uygulanan güvenirlik katsayısı 0.817 olarak belirlenmiştir. $\mathrm{Bu}$ değer anketin güvenirliliğinin oldukça iyi olduğunu göstermektedir.

Etik davranışların ölçümü için öğrencilere verilen senaryolarda, öğrencilere doğru cevabın bulunmadığı ve isimsiz değerlendirileceği belirtilmiştir.

\section{Amaç}

Araştırmada ASÜ OMYO öğrencilerinin sahip oldukları etik davranışlar tespit edilerek, gerek etik eğitiminin müfredat açısından, gerekse mezuniyet sonrası çalışacakları mesleğe ilişkin "meslek etiğine" ilişkin algıları ve bu duruma ilişkin için tespit ve değerlendirmelerin yapılması amaçlanmaktadır.

\section{Bulgular ve Analizi}

Araştırmaya 335 öğrenci katılmıştır. Araştırma evrenine ait demografik verilerle ilgili frekans değerleri Tablo 2'de verilmiştir.

\begin{tabular}{lll}
\hline Tablo 2. Araştırma Evrenine Ait Demografik Bulgular & & \\
\hline Cinsiyet & Frekans & Yüzde (\%) \\
\hline Erkek & 112 & 33,4 \\
\hline Kadın & 223 & 66,6 \\
\hline & & \\
\hline Yaş & Frekans & Yüzde (\%) \\
\hline $17-21$ & 270 & 80,6 \\
\hline $22-26$ & 63 & 18,8 \\
\hline 27 ve üstü & 2 & 0,6 \\
\hline
\end{tabular}


Tablo 2 Devamı:

\begin{tabular}{|c|c|c|}
\hline Ailenin İkamet Ettiği Bölge & Frekans & Yüzde (\%) \\
\hline Marmara & 25 & 7,5 \\
\hline İç Anadolu & 167 & 49,9 \\
\hline Akdeniz & 94 & 28,1 \\
\hline Doğu Anadolu & 7 & 2,1 \\
\hline Güney Doğu Anadolu & 33 & 9,9 \\
\hline Karadeniz & 5 & 1,5 \\
\hline Ege & 4 & 1,2 \\
\hline Sinıf & Frekans & Yüzde (\%) \\
\hline 1. Sinif & 155 & 46,3 \\
\hline 2. Sinif & 178 & 53,1 \\
\hline Öğrencilerin Yetiştiği Yeri Tanımlaması & Frekans & Yüzde (\%) \\
\hline Köy ya da Belde & 71 & 21,2 \\
\hline İlçe Merkezi & 106 & 31,6 \\
\hline Orta Büyüklükteki Bir İl Merkezi & 44 & 13,1 \\
\hline Büyükşehir & 114 & 34 \\
\hline Planlanan Mesleki Kariyer Alanı & Frekans & Yüzde (\%) \\
\hline Bankacıl1k-Finans & 145 & 43,3 \\
\hline Serbest Meslek & 12 & 3,6 \\
\hline Kamu Sektörü & 82 & 24,5 \\
\hline Pazarlama & 5 & 1,5 \\
\hline Girişimci olarak & 17 & 5,1 \\
\hline Mali Müşavirlik & 73 & 21.8 \\
\hline Diğer & 1 & 0,3 \\
\hline $\begin{array}{l}\text { Mezun Olduktan Sonra Kariyer Kaygısı Taşıma } \\
\text { Durumları }\end{array}$ & & \\
\hline Evet & 179 & 53,4 \\
\hline Kismen & 97 & 29 \\
\hline Hayır & 59 & 17,6 \\
\hline
\end{tabular}

Tablo-2 incelendiğinde katılımcıların \%66,6'sının bayan, \%33,4'ünün ise erkek olduğu görülmektedir. Öğrencilerin ailelerinin büyük bir bölümünün $(\% 49,9)$ İç Anadolu bölgesinde ikamet ettiği belirlenmiştir. Öğrencilerin \%43,3'ü Bankacıllk - Finans sektöründe, \%24,5'i kamu sektöründe ve \%21,8'i mali müşavir mesleğinde kariyer planlaması yapmaktadır. Ayrıca öğrencilerin mezun olduktan sonra \%53,4'ünün kariyer kaygısı taşıdığ 1 \%29'unun kısmen kariyer kaygısı taşıdığı, \%17,6'sının ise kariyer kaygısı taşımadığı görülmektedir.

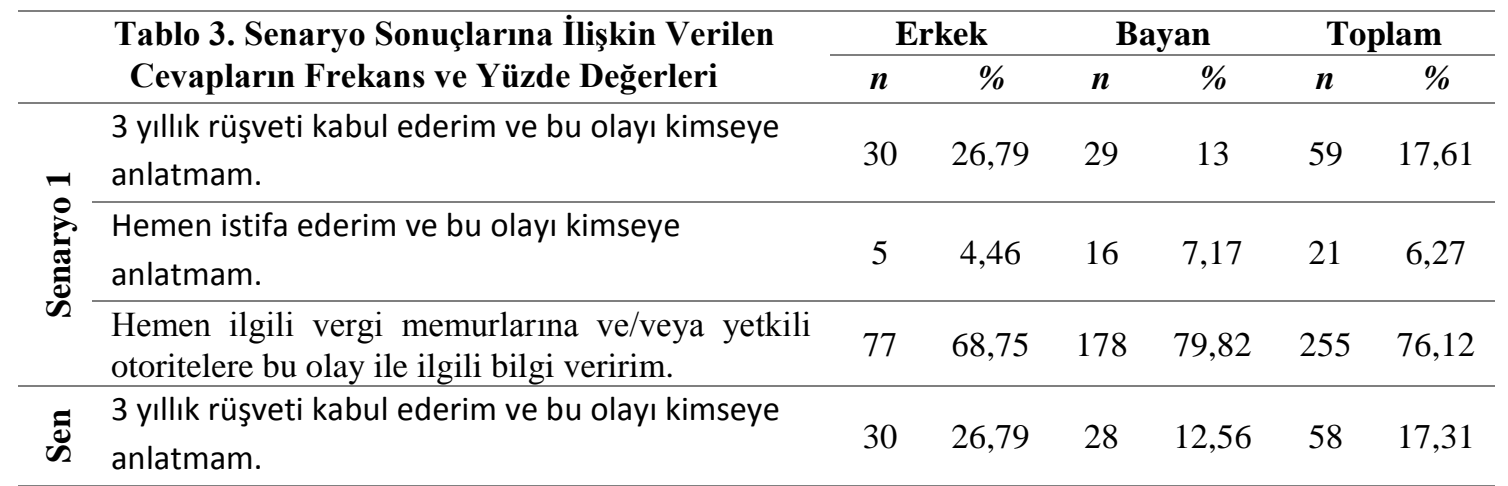




\begin{tabular}{|c|c|c|c|c|c|c|c|}
\hline & $\begin{array}{l}\text { Hemen istifa ederim ve bu olayı kimseye } \\
\text { anlatmam. }\end{array}$ & 14 & 12,50 & 36 & 16,14 & 50 & 14,93 \\
\hline & $\begin{array}{l}\text { Hemen ilgili vergi memurlarına ve/veya yetkili } \\
\text { otoritelere bu olay ile ilgili bilgi veririm. }\end{array}$ & 68 & 60,71 & 159 & 71,30 & 227 & 67,76 \\
\hline \multirow{3}{*}{ } & $\begin{array}{l}3 \text { yıllık rüşveti kabul ederim ve bu olayı kimseye } \\
\text { anlatmam. }\end{array}$ & 36 & 32,14 & 44 & 19,73 & 80 & 23,88 \\
\hline & $\begin{array}{l}\text { Hemen istifa ederim ve bu olayı kimseye } \\
\text { anlatmam. }\end{array}$ & 15 & 13,39 & 36 & 16,14 & 51 & 15,22 \\
\hline & $\begin{array}{l}\text { Hemen ilgili vergi memurlarına ve/veya yetkili } \\
\text { otoritelere bu olay ile ilgili bilgi veririm. }\end{array}$ & 61 & 54,46 & 143 & 64,13 & 204 & 60,9 \\
\hline \multirow{3}{*}{ 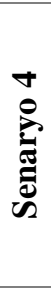 } & $\begin{array}{l}3 \text { yıllık rüşveti kabul ederim ve bu olayı kimseye } \\
\text { anlatmam. }\end{array}$ & 30 & 26,79 & 31 & 13,90 & 61 & 18,21 \\
\hline & $\begin{array}{l}\text { Hemen istifa ederim ve bu olayı kimseye } \\
\text { anlatmam. }\end{array}$ & 17 & 15,18 & 30 & 13,45 & 47 & 14,03 \\
\hline & $\begin{array}{l}\text { Hemen ilgili vergi memurlarına ve/veya yetkili } \\
\text { otoritelere bu olay ile ilgili bilgi veririm. }\end{array}$ & 65 & 58,04 & 162 & 72,65 & 227 & 67,76 \\
\hline \multirow{3}{*}{ 袋 } & $\begin{array}{l}\text { Arda'nın teklifini kabul ederim ve muhasebe } \\
\text { sınav sorularını önceden alırım. }\end{array}$ & 64 & 57,14 & 143 & 64,13 & 207 & 61,79 \\
\hline & $\begin{array}{l}\text { Ona teklifi için teşekkür ederim ama teklifini } \\
\text { reddederim. }\end{array}$ & 38 & 33,93 & 69 & 30,94 & 107 & 31,94 \\
\hline & $\begin{array}{l}\text { Ona teklifi için teşekkür ederim ama teklifini } \\
\text { reddederim. Ve hemen çalıştığ } 1 \text { firmanın } \\
\text { yetkililerine Arda'nın size yaptığ } 1 \text { bu teklifi } \\
\text { anlatırım. }\end{array}$ & 10 & 8,93 & 11 & 4,93 & 21 & 6,27 \\
\hline \multirow{3}{*}{ 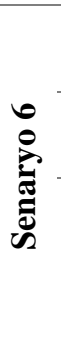 } & $\begin{array}{l}\text { Arda'nın teklifini kabul ederim ve muhasebe } \\
\text { sınav sorularını önceden alırım. }\end{array}$ & 51 & 45,54 & 109 & 48,88 & 160 & 47,76 \\
\hline & $\begin{array}{l}\text { Ona teklifi için teşekkür ederim ama teklifini } \\
\text { reddederim. }\end{array}$ & 45 & 40,18 & 98 & 43,95 & 143 & 42,69 \\
\hline & $\begin{array}{l}\text { Ona teklifi için teşekkür ederim ama teklifini } \\
\text { reddederim. Ve hemen çalıştığı firmanın } \\
\text { yetkililerine Arda'nın size yaptığı bu teklifi } \\
\text { anlatırım. }\end{array}$ & 16 & 14,29 & 16 & 7,17 & 32 & 9,55 \\
\hline
\end{tabular}

Tablo 3 incelendiğinde vergi kaçırma ve ortaklardan kaçırma senaryolarına öğrenciler tarafından büyük bir çoğunlukla $(\% 76,12, \% 67,76, \% 60,9, \% 67,16)$ gerekli otoritelere bilgi verme şıkkının seçildiği görülürken, okulu bitirmeleri ile ilgili senaryo olan 5 ve 6 . senaryolara büyük bir çoğunlukla (\%61,79, \%47,76) kabul etme şıkkını seçtikleri belirlenmiştir. Ayrıca olası senaryolarda yakalanma riski söz konusu olduğunda kabul etme ve bilgi verme şıklarının oranı azalmış ve reddetme şıkkının oranı artmıştır.

Öğrencileri mesleki kariyerlerinde kendilerine teklif edilen etik dışı davranışlarda özellikle kamuyu ilgilendiren konularda net bir tutum sergileyerek kanunlar çerçevesinde hareket edilmesini benimsemekte iken konu mesleki kariyerine ilişkin etik dışı bir davranışla birlikte olumlu etki edecek bir davranışı (\%45,54 erkek ve $\% 48,88$ bayan) kabul etmekte ya da nazikçe reddetmektedir (\%40,18 erkek, \%43,95 bayan). Bu durum katılımcıların senaryo yerine gerçek bir olay karşısındaki kariyerine ilişkin seçenekte etik dışı davranışlar içerisine gireceğini göstermektedir.

Etik kararlar üzerine öğrencilerin cinsiyetlerinin etkisini ölçmek için yapılan analiz sonuçları aşağıdaki gibidir.

\begin{tabular}{|c|c|c|c|c|c|}
\hline $\begin{array}{c}\text { Tablo 4. Cinsiyete Göre Grup } \\
\text { Ortalamalarına Göre t Testi Sonuçları }\end{array}$ & Cinsiyet & Sayı & Ortalama & $\begin{array}{l}\text { Standart } \\
\text { Sapma }\end{array}$ & $\begin{array}{l}\text { Sig. } \\
\text { (p) }\end{array}$ \\
\hline \multirow{2}{*}{ Senaryo 1} & Erkek & 112 & 2,4196 & 0,88672 & \multirow{2}{*}{0,010} \\
\hline & Kadın & 223 & 2,6682 & 0,69569 & \\
\hline \multirow{2}{*}{ Senaryo 2} & Erkek & 112 & 2,3393 & 0,87563 & \multirow{2}{*}{0,010} \\
\hline & Kadın & 223 & 2,5874 & 0,70406 & \\
\hline \multirow{2}{*}{ Senaryo 3} & Erkek & 112 & 2,2232 & 0,90752 & \multirow{2}{*}{0,030} \\
\hline & Kadın & 223 & 2,4439 & 0,80272 & \\
\hline
\end{tabular}




\begin{tabular}{lllllll}
\hline \multirow{2}{*}{ Senaryo 4 } & Erkek & 112 & 2,3125 & 0,87024 & \multirow{2}{*}{0,004} \\
\cline { 2 - 5 } & Kadın & 223 & 2,5874 & 0,72300 & \\
\cline { 2 - 5 } \multirow{2}{*}{ Senaryo 5 } & Erkek & 112 & 1,5179 & 0,65735 & \multirow{2}{*}{0,136} \\
\cline { 2 - 5 } & Kadın & 223 & 1,4081 & 0,58458 & \multirow{2}{*}{ Senaryo 6 } \\
\cline { 2 - 5 } & & Erkek & 112 & 1,6875 & 0,71068 & 0,168 \\
\cline { 2 - 5 } & & Kadın & 223 & 1,5830 & 0,62318 & \\
\hline
\end{tabular}

Tablo 4 incelendiğinde vergi kaçırma ve hissedarların dolandırılması senaryolarında erkek ve kız öğrenciler arasında Sig. (p) değerleri 0,05'ten küçük olduğundan H0 hipotezi red edilmiş, H1 hipotezi kabul edilmiştir. Sınav sorularını önceden elde etme senaryolarında ise Sig. (p) değerleri 0,05 'ten büyük olduğundan gruplar arası anlamlı bir fark bulunamamıştır ve H0 hipotezi kabul edilmişstir.

$\mathbf{H}_{\mathbf{0}}$ : Cinsiyet ile etik davranış düzeyleri arasında farklılık yoktur.

$\mathbf{H}_{1}$ : Cinsiyet ile etik davranış düzeyleri arasında farklılık vardır.

Araştırmaya katılan öğrencilerden alınan cevaplara göre, etik davranışlar üzerinde öğrenim görülen sınıflar arsında farklılık olup olmadığının karşılaştırılması amacıyla bağımsız örneklem t testi uygulanmıştır. Buna göre kurulan hipotezler ve analiz sonuçları aşağıdaki gibidir.

$\mathbf{H}_{2}$ : Öğrenim görülen sınıf ile etik davranış düzeyleri arasında farklılık yoktur.

$\mathbf{H}_{3}$ : Öğrenim görülen sınıf ile etik davranış düzeyleri arasında farklılık vardır.

\begin{tabular}{cccccccc}
\hline \multicolumn{6}{c}{ Tablo 5. Sınıfa Göre Grup Ortalamalarına Göre t Testi Sonuçları } \\
\hline \multirow{2}{*}{ Öğrenim Görülen Sınıf } & \multirow{n}{*}{} & $\begin{array}{c}\text { Aritmetik } \\
\text { Ortalama }\end{array}$ & $\begin{array}{c}\text { Standart } \\
\text { Sapma }\end{array}$ & t & df & p \\
\hline 1.Sınıf & 155 & 2,1527 & 0,57546 & $-0,504$ & 331 & 0,615 \\
\hline 2.Sınıf & 178 & 2,1826 & 0,50723 & & & \\
\hline
\end{tabular}

Tablo 5'e göre Sig.(p) değerinin 0,05 'ten büyük olmasından dolayı $\mathrm{H}_{3}$ hipotezi kabul, $\mathrm{H}_{4}$ hipotezi reddedilmiştir. Öğrenim görülen sınıfın etik davranış düzeyi üzerinde anlamlı bir etkisi yoktur. Başka bir ifade ile etik davranışlar konusunda MYO'larda verilen eğitimin etkisi; böyle bir dersin mevcut olmaması ve/veya bu konuda yeterli eğitimin verilmediği algısının yanında, öğrencilerin etik davranışlara ilişkin tutum ve davranışlarını din, aile, yaşadığı çevre, çevre baskısı vb. faktörler şekillendirdiği için öğrenim seviyesi nispeten daha etkili olabilmektedir.

Planlanan mesleki kariyer alanı ile etik davranışlar arasında farklılık olup olmadığının karşılaştırılması amacıyla Anova testi uygulanmıştır. Buna göre kurulan hipotezler ve analiz sonuçları aşağıdaki gibidir.

$\mathbf{H}_{4}$ : Planlanan mesleki kariyer alanı ile etik davranış düzeyleri arasında farklılık yoktur.

$\mathbf{H}_{5}$ : Planlanan mesleki kariyer alanı ile etik davranış düzeyleri arasında farklılık vardır.

\begin{tabular}{lccc}
\hline \multicolumn{3}{c}{ Tablo 6. Planlanan Mesleki Kariyer Alanlarına Göre Grup Ortalamaları } \\
\hline $\begin{array}{l}\text { Planlanan } \\
\text { Kariyer Alanları }\end{array}$ & $\mathrm{n}$ & Mean & Std. Deviation \\
\hline Bankacılık - Finans & 145 & 2,1713 & 0,55727 \\
\hline Serbest Meslek & 12 & 1,9583 & 0,65569 \\
\hline Kamu Sektörü & 82 & 2,3008 & 0,44013 \\
\hline Pazarlama & 5 & 1,9667 & 0,74907 \\
\hline Girişimci & 17 & 1,7647 & 0,55920 \\
\hline Mali Müşavirlik & 74 & 2,1622 & 0,51535 \\
\hline
\end{tabular}

Tablo 7. Planlanan Mesleki Kariyer Alanlarına Göre ANOVA Testi Sonuçları

\begin{tabular}{|c|c|c|c|c|}
\hline $\begin{array}{l}\text { Sum of } \\
\text { Squares }\end{array}$ & $\mathrm{df}$ & $\begin{array}{c}\text { Mean } \\
\text { Square }\end{array}$ & $\mathrm{F}$ & Sig. \\
\hline
\end{tabular}




\begin{tabular}{|c|c|c|c|c|c|c|}
\hline Senaryo_Mean & Between Groups & 4,945 & 5 & 0,989 & 3,545 & 0,004 \\
\hline & Within Groups & 91,774 & 329 & 0,279 & & \\
\hline & Total & 96,719 & 334 & & & \\
\hline Sektör & $\begin{array}{l}\text { Karşılaştırılan } \\
\text { Sektör }\end{array}$ & $\begin{array}{c}\text { Mean } \\
\text { Difference }\end{array}$ & $\begin{array}{l}\text { Std. } \\
\text { Error }\end{array}$ & & Sig. & \\
\hline \multirow[t]{5}{*}{ Kamu Sektörü } & Bankacılık - Finans & 0,12955 & 0,06711 & & 0,572 & \\
\hline & Serbest Meslek & 0,34248 & 0,19542 & & 0,808 & \\
\hline & Pazarlama & 0,33415 & 0,33850 & & 0,999 & \\
\hline & Girişimci & $0,53611^{*}$ & 0,14407 & & 0,020 & \\
\hline & Mali Müşavirlik & 0,13865 & 0,07714 & & 0,686 & \\
\hline
\end{tabular}

Tablo 7'ye göre Sig. Değeri 0,05 'ten küçük olduğu için $\mathrm{H}_{5}$ hipotezi kabul edilmiştir. Anova testi sonucunda planlanan mesleki kariyer alanları arasında yalnızca kamu sektründe kariyer planlayan öğrenciler ile girişimci olarak mesleki kariyer planlaması yapan öğrenciler arasında farklılık tespit edilmiştir. Söz konusu diğer gruplar açısından istatistiksel olarak anlamlı bir farklılık bulunmamaktadır.

Bu bağlamda Tablo 6'ya göre grupların ortalaması ele alındığında kamu sektöründe çalışmayı düşünen öğrencilerin senaryolara verdikleri cevapların ortalamaları 2,3008 iken girişimci olarak mesleki kariyer planlaması yapan öğrencilerin ortalaması 1,7647 olarak belirlenmiştir. Bu sonuçlara göre kamu sektöründe kariyer planlaması yapan öğrencilerin daha sağlamcı olduğu ve garanti iş imkânına göre tercih ettiği göz önünde bulundurulursa bu öğrencilerin girişimci öğrencilere göre daha etik bir tutum sergilemesi sonucuna ulaşmak şaşırtıcı olmayacaktır.

\section{Sonuç ve Öneriler}

ASÜ OMYO'da eğitim gören ve genel muhasebe dersi almış öğrencilere, etik davranışlarını tespit etmek amacıyla toplam 335 anket yapılmış ve aşağıdaki sonuçlara ulaşılmıştır.

- Araştırmaya katılan öğrencilerin, vergi kaçırma ve hissedarları dolandırma senaryolarına rüşveti kabul etme oranları $(\% 17,61, \% 17,31, \% 23,88, \% 18,21)$ olarak tespit edilmişken, sınav sorularında önceden elde etme senaryolarında etik dışı davranışı tercih edenlerin oranları $(\% 61,79, \% 47,76)$ olarak belirlenmiştir. Buna göre öğrenciler, kendilerine haksız kazanç sağlayacak rüşvet gibi etik dışı davranışları benimsemezken, okulu bitirmeleri ve iş bulmalarını sağlayacak muhasebe final sorularını önceden almayı kabul etmişler ve bu davranışı etik dışı davranış olarak değerlendirmemişlerdir.

- Öğrencilerin etik kararları üzerine cinsiyet farklılığının etkisine ait analiz bulguları Tablo 4'te verilmiştir. Buna göre vergi kaçırma ve hissedarları dolandırma senaryolarında $\mathrm{H}_{1}$ hipotezi kabul edilmiş $(p<0,05)$, cinsiyet ve etik davranışlar arasında farklılık bulunduğu saptanmıştır. Söz konusu senaryolarda grup ortalamaları incelendiğinde (Tablo 4), bayan öğrencilerin ortalamalarının, erkek öğrencileri ortalamalarına göre 3'e daha yakın olduğu görülmektedir ki beklenen etik davranış 3. şık olarak belirlenmiştir. Bu bağlamda etik davranışlar ile ilgili diğer çalışmalarda ulaşılan sonuçları destekler nitelikte bayanların erkeklere göre daha etik davranışlar sergilemeye yatkın oldukları söylenebilir.

- Sınav sorularını önceden elde etme senaryolarına yönelik cinsiyet farklılı̆̆ının etkisini ölçmek amacıyla yapılan analizde ise $\mathrm{H}_{0}$ hipotezi kabul edilmiş $(\mathrm{p}>0,05)$ ve öğrencilerin gelecekleri ile ilgili okulu bitirmelerine yardımcı olacak etik dışı davranışlarda cinsiyet farklılığının olmadığı saptanmıştır.

- Senaryolarda yakalanma riski olduğu durumlarda (senaryo 2-4-6), öğrencilerin rüşveti veya sınav sorularını önceden alma seçeneğinde kabul oranlarının yakalanma risk olmayan senaryolara göre (senaryo $1-3-5$ ) azaldığı görülmektedir. Buna göre yakalanma risk faktörünün öğrencileri etik davranışlara yöneltmekte olduğu söylenebilir.

- Öğrenim görülen sınıf ile etik davranış düzeyleri arasındaki farklılık incelendiğinde, herhangi bir farklılık olmadığı belirlenmiştir.

Sonuç olarak; muhasebe mesleği bir yönü ile topluma bir yönü ile işverene karşı sorumludur. Bu yönü ile muhasebecilik mesleğinin gerektirdiği teknik uzmanlığın yanında etik değerlere de sahip olmalıdır. Çünkü mesleğe yönelik toplumsal güvenin korunması ve kaynakların etkin / verimli kullanımı için ihtiyaç duyulan bilginin elde edilmesi, gelirin yeniden dağılımında vergisel adaletin sağlanması ve kamunun ihtiyaç duyduğu kaynaklara ulaşması vb. birçok faktör açısından meslek ile ilgili etik değerler büyük önem arz etmektedir. 
İşletmelerin ihtiyaç duyduğu muhasebe meslek elemanlarının yetiştirilmesi büyük ölçüde MYO ve İ.İ.B.F.'leri tarafından karşılanmaktadır. Bu nedenle etik değerlerin önlisans/lisans eğitiminde verilmesi ve bu bakış açısının öğrencilere kazandırılması, öğrencilerin iş hayatlarına etik değerlere bağlı kalmasında önemli bir rol oynayacaktır. Bu bağlamda muhasebede etik konularının "Genel Muhasebe" ve "Muhasebe Denetimi" dersleri içinde sunulması ve "Muhasebe Meslek Etiği”" dersinin müfredata eklenmesi öğrencilere; etik, meslek etiği, muhasebe meslek etiği, meslekte karşılaşılabilecek etik ikilemleri değerlendirme vb. konularda kazanımlar sağlayacaktır.

Son olarak muhasebecilik mesleğini icra etmeyi düşünen kişilerin teknik eğitimden ve mesleğe giriş izni verilmeden önce; etik eğitimi verilmesi ve çeşitli psikolojik testlerden geçirilmesi ile mesleğe kabulünde ön şart olarak uygulanması gerekir. Etik değerleri taşımayan kişilere ise mesleğe giriş izni verilmemesi uygun olacaktır.

Gelecek araştırmacılar için bu anketin etik eğitimi alanlar ve almayanlar açısından eğitim dönemini başında ve sonunda olmak üzere uygulanması ile öğrencilerin etik davranışlarında ki değişim zaman ve eğitim boyutu dikkate alınarak daha sağlıklı ölçülebilir. 


\section{KAYNAKÇA}

Ağyar, E., Kutluk, F. A., \& Cengiz, E. (2012). Meslek Yüksekokulları Muhasebe Bölümü Öğrencilerinin Sosyo-Ekonomik Değişkenler Işı̆̆ında Mesleki Etiğe Bakış Açılarının İncelenmesi (Akdeniz Üniversitesi Örneği). Journal of Yasar University, 25(7), 4203-4228.

Akın, O., \& Özdaşlı, K. (2014, Temmuz). Muhasebe Meslek Mensuplarının Mesleki Faaliyetlerinde Uymaları Gereken Etik İlkelere Uyma Düzeyine Yönelik Meslek Mensupları İle Meslek Yüksek Okulu Muhasebe Bölümü Öğrencilerinin Algıları. Muhasebe ve Finansman Dergisi, 59-73.

Alam, K. F. (1998). Ethics and Accounting Education. Teaching Business Ethics, 2(3), 261-272.

Alkan, G. İ. (2015). Muhasebe Eğitiminde Etik: Ön Lisans Öğrencilerinin Etik Algılarına Yönelik Bir Araştırma. Business and Economics Research Journal, 6(2), 113-125.

Allen, P. W. (2005). Principled Accounting Ethics Should Be Taught. Journal of Accounting and Finance Research, 13(3), 41-53.

Ameen, E. C., Guffey, D. M., \& McMillan, J. J. (1996). Gender Differences in Determining the Ethical Sensitivity of Future Accounting Professionals. Journal of Business Ethics(15), 591-597.

Armstrong, M. B., Ketz, J. E., \& Owsen, D. (2003). Ethics Education in Accounting: Moving Toward Ethical Motivation and Ethical Behavior. Journal of Accounting Education(21), 1-16.

Aymankuy, Y., \& Sarığlan, M. (2015). Muhasebe Meslek Mensuplarının Meslek Etiğine Yaklaşımları ve Balıkesir İl Merkezinde Bir Uygulama. Balıkesir Üniversitesi Sosyal Bilimler Dergisi, 8(14), 23-45.

Balsarı, Ç. K., Dalkılıç, F., Öz, İ., \& Cagle, M. N. (2014). Muhasebede Etik Eğitiminde Çağdaş Bir Model: Bütünleşik Öğretim Uygulamas1. Muhasebe ve Denetime Bakış, 69-80.

Bezirci, M., \& Bayraktar, M. K. (2015). Dört Kutsal Kitap ve Ahilik Çerçevesinde Karşılaştırmalı Olarak Etik ve Muhasebe Meslek Mensuplarında Etik Eğitimi. Muhasebe Bilim Dünyası Dergisi, 17(2), 385-412.

Bilen, A., \& Yılmaz, Y. (2014). Muhasebe Mesleğinde Etik ve Etikle İlgili Çalışmalar. Dicle Üniversitesi Iktisadi ve İdari Bilimler Fakültesi Dergisi, 2(6), 57-72.

Bitlisli, F., \& Dinç, M. (2015). Makyavelist Kişilk Eğilimleri ve Etiksel Karar Verme Davranışı İlişkisi: Muhasebe Meslek Mensupları Üzerine Bir Araştırma. Muhasebe Bilim Dünyası Dergisi, 17(4), 921 942.

Büyükyılmaz, O., \& Gürkan, S. (2014, Temmuz-Ağustos). Mesleki Tükenmişliğin Muhasebe Meslek Mensuplarının Etik Tutumları Üzerindeki Etkisi. Mali Çözüm, 129-148.

Cohen, J. R., \& Bennie, N. M. (2006). The Applicability of a Contingent Factors Model to Accounting Ethics Research. Journal of Business Ethics(68), 1-18.

Cohen, J. R., Pant, L. W., \& Sharp, D. J. (1998). The Effect of Gender an Academic Discipline Diversity on the Ethical Evaluations, Ethical Intentions and Ethical Orientation of Potential Public Accounting Recruits. Accounting Horzions, 12(3), 250-270.

Conroy, S. J., \& Emerson, T. L. (2006). Changing Ethical Attitudes: The Case of the Enron and ImClone Scandals. Social Science Quarterly, 87(2), 395-410.

Çevik, İ., \& Dağdeviren, İ. E. (2015). Muhasebe Meslek Mensuplarının Etik Algılamaları ve Muhasebe Meslek Mensuplarını Etik Dışı Davranışlara Yönlendiren Faktörler: Göller Bölgesinde Bir Araştırma. Muhasebe ve Vergi Uygulamaları Dergisi, 8(1), 67-89.

Daştan, A. (2009). Etik Eğitiminin Muhasebe Eğitimindeki Yeri ve Önemi: Türkiye Değerlendirmesi. 26(1), 281-311.

Daştan, A., Bayraktar, Y., \& Bellikli, U. (2015). Muhasebe Mesleğinde Etik İkilem ve Etik Karar Alma Konularında Farkındalık Oluşturma: Trabzon İlinde Bir Araştırma. Atatürk Üniversitesi İktisadi ve İdari Bilimler Dergisi, 29(1), 63-82.

Dinç, E., \& Tunçer, M. (2015). Muhasebe Meslek Mensuplarının Etik Duyarlılıkları ile İlgili Vergi Müfettişlerinin Algılarına Yönelik Bir Araştırma. International Journal of Economic and Administrative Studies(14), 317-338.

Elias, R. Z., \& Farag, M. S. (2011). The Impact of Accounting Students' Type A Personality and Cheating Opportunity on Their Ethical Perception. Journal of the Academy of Business Education, 71-84. 
Ergün, H., \& Gül, K. (2005). Muhasebe Mesleği Etik Kuralları ve Bu Kuralların Meslek Mensuplarınca Algılanış1. Muhasebe ve Finansman Dergisi(25), 144-154.

Fidan, M. E., \& Subaşı, Ş. (2014, Ekim). Muhasebe Meslek Mensubu Adaylarının Etik Algıları: İstanbul İli Örneği. Muhasebe ve Finansman Dergisi, 111-130.

Hacıhasanoğlu, T. (2013). Sakarya İlinde Faaliyet Gösteren Bağımsız Muhasebecilerin Meslek Etiği Algılama Düzeylerine İlişkin Bİr Araştırma. C.Ü. İktisadi ve İdari Bilimler Dergisi, 14(1), 357-372.

Harrington, S. J. (1997). A Test of a Person-Issue Contingent Model of Ethical Decision Making in Organizations. Journal of Business Ethics, 16(4), 363-375.

Kaya, N., \& Yanık, R. (2011). Muhasebe Meslek Ahlakı, Etik ve Müşteri Tatmini İlişkisi. Ekev Akademi Dergisi(49), 293-306.

Kısakürek, M. M., \& Alpan, N. (2010). Muhasebe Meslek Etiği ve Bir Uygulama. Muhasebe ve Finansman Dergisi(47), 213-228.

Klimek, J., \& Wenell, K. (2011). Ethics in Accounting: An Indispensable Course? Academy of Educational Leadership Journal, 15(4), 107-118.

Kurnaz, N., \& Gümüş, Y. (2010). Muhasebe Bölümü Öğrencilerinin Muhasebe Mesleği İle İlgili Etik Dış1 Davranışlara İlişkin Algı Analizi: Dumlupınar Üniversitesi Uygulamalı Bilimler Yüksekokulu Örneği. Muhasebe ve Finansman Dergisi(46), 157-174.

Kutluk, F. A., \& Ersoy, A. (2011). Muhasebe Meslek Üyelerinin Etik Yarg1 Düzeyleri Üzerine Bir Araştırma. Ege Akademik Bakıs, 11(3), 425-438.

Loeb, S. E. (1988). Teachin Students Accounting Ethics - Some Crucial Issues. Issues in Accounting Education, 3(2), 316-329.

Mahdavikhou, M., \& Khotanlou, M. (2012). New Approach to Teaching of Ethics in Accounting "Introducing Islamic Ethics into Accounting Education". Procedia - Social and Behavioral Sciences(46), 1318-1322.

McPhail, K. (1999). The Threat of Ethical Accountants: An Application of Foucault's Concept of Ethics to Accounting Education an Some Thoughts on Ethically Educating for the Other. Critical Perspectives on Accounting(10), 833-866.

Meymandi, A. R., Rajabdoory, H., \& Asoodeh, Z. (2015). The Reasons of Considering Ethics in Accounting Job. International Journal of Management, Accounting and Economics, 2(2), 136-143.

Mintz, S. M. (2006). Accounting Ethics Education: Integrating Reflective Learning and Virtue Ethics. Journal of Accounting Education(24), 97-117.

O'Leary, C., \& Radich, R. (2001). An Analysis of Australian Final Year Accountancy Students' Ethical Attitudes. Teaching Business Ethics, 5(3), 235-249.

Otlu, F. (1999). Muhasebe Mesleğinde Meslek Ahlakının Yeri ve Önemi. Süleyman Demirel Üniversitesi İiBF Dergisi(4), 125-142.

Özkan, A. H. (2014). Akademisyenlerin Etik Eğitime Bakışı: Türkiye ve ABD Örneği. Journal of Yasar University, 9(34), 5787-5795.

Sakarya, Ş., \& Kara, S. (2010). Türkiye'de Muhasebe Meslek Etiğine Yönelik Düzenlemeler ve Meslek Mensupları Tarafindan Algılanması Üzerine Bir Alan Araştırması. KMÜ Sosyal ve Ekonomik Araştırmalar Dergisi, 12(18), 57-72.

Seymen, O. A., \& Bolat, T. (2007). Kohlberg'in Bilişsel Ahlaki Gelişim Modelinden Yararlanan Etiksel Karar Verme Modellerinin Karşılaştırmalı Analizi. Akdeniz İ.I.B.F. Dergisi(13), 24-61.

Subaşı, Ş., \& Fidan, M. E. (2015). Muhasebe Meslek Mensubu Adaylarının Etik Eğitimi Görüşleri. Muhasebe Bilim Dünyası Dergisi, 17(3), 667-700.

Şahin, A. C., \& Dağlı, S. Ş. (2014). Muhasebe Meslek Etiği ve Meslek Mensuplarının Etik Hakkındaki Görüşleri Üzerine Isparta ilinde Bir Araştırma. Süleyman Demirel Üniversitesi Sosyal Bilimler Enstitüsü Dergisi(20), 55-84.

Thorne, L. (1998). The Role of Virtue in Auditors' Ethical Decision Making: An Integration of Cognitive Developmental and Virtue-Ethics Perspectives. Research on Accounting Ethics(4), 291308. 
Thorne, L. (1999). An Analysis of the Association of Demographic Variables with the Cognitive Moral Development of Canadian Accounting Students. Journal of Accounting Education, 17(2-3), 157-174.

Thorne, L. (2000). The Development of Two Measures to Assess Accountants' Prescriptive and Deliberative Moral Reasoning. Behavioral Research in Accounting, 12, 139-169.

Thorne, L. (2001). Refocusing Ethics Education in Accounting: An Examination of Accounting Students' Tendency to use their Cognitive Moral Capability. Journal of Accounting Education, 19(2), 103-117.

Trevino, L. K. (1986). Ethical Decision Making in Organizations: A Person-Situation Interactionist Model. Academy of Management Review, 11(3), 601-617.

Utku, B. D. (2009). Etik Davranışlar: Muhasebe Meslek Mensubu Olmaya Aday İ̈BF Öğrencileri Üzerine Bir Araştırma. MÖDAV, 211-232.

Wyatt, A. R. (2004). Accounting Professionalism-They Just Don't Get It! Accounting Horizons, 18(1), 4553.

Yalçın, S. (2011, Ekim). Muhasebe Meslek Mensupları ve İşletmelerin Etik Konusunda Tutumları: Türkiye Araştırması. Muhasebe ve Finansman Dergisi, 47-66.

Yardımcıoğlu, M., \& Ada, Ş. (2013). Kronolojik Bir Sirayla Muhasebe ve Finansal Raporlamada Usulsüzlük ve Skandallar. Kahramanmaraş Sütçü Imam Üniversitesi İktisadi ve İdari Bilimler Dergisi(1), 43-56.

Yıldız, G. (2010). Muhasebe Mesleğinde Meslek Etiği ve Kayseri İl Merkezinde Bir Uygulama. Erciyes Üniversitesi İktisadi ve İdari Bilimler Fakültesi Dergisi(36), 155-178.

Yılmaz, E., Yıldırım, S., \& Bahar, H. H. (2015, Ocak). Serbest Muhasebeci Mali Müşavirlerin Mesleki Etik Algıs1: Samsun Örneği. Muhasebe ve Finansman Dergisi, 27-41. 


\section{Ek: Anket Formu}

\section{Değerli öğrenciler,}

Bu anket etik davranış ve ölçümünü belirlemek üzere hazırlanmıştır. Aşağıda verilen senaryoların doğru ya da yanlış bir cevabı bulunmamaktadır. Sizin yapacağınız değerlendirme; mevcut durumu belirlemeye önemli katkılar sağlayacaktır. Tüm soruları eksiksiz ve samimiyetle doldurmanızı rica eder, katkılarınız için teşekkür ederiz.

\section{Senaryo 1:}

Üniversiteyi bitirdiniz ve ilk işinizde altı ay geçirdiniz. Büyük bir üretim firmasında muhasebe asistanısınız. Altı ay sonra, yıllık olarak 400.000 TL'lik bir vergi faturasının ödenmemesini sağlayan zekice düzenlenmiş bir vergi kaçırma planının işletmenizde var olduğunu fark ediyorsunuz. Daha sonra patronunuz ile muhasebe sorumlunuzu yüzleştiriyorsunuz ve patronunuzun yasal olmayan bu plana müsaade ettiğini görüyorsunuz. Patron ve geride kalan üç yönetici, bu miktarı eşit olarak aralarında bölüşüyorlar (her biri yıllık olarak 100.000 TL alıyor). Bu planın mükemmel şekilde üstü kapatılmış, ayrıca mevcut vergi çalışanları inanılmaz derecede yetersiz, işleyiş ve denetimlerinde çok zayıflar. Siz de artık eminsiniz ki, bu vergi kaçırma planının ortaya çıkmasına imkân yok.

Patronunuz size üç yıl için her bir yılbaşına maaşınızdan oldukça yüksek bir meblağ olarak 80.000 TL teklif ediyor. Ve siz bu vergi kaçırma olayını değiştiremiyorsunuz.

Lütfen bu olay ile ilgili düşüncenizi (yalnızca 1 seçenek) işaretleyiniz.

(1) 3 yıllık rüşveti kabul ederim ve bu olayı kimseye anlatmam.

(2) Hemen istifa ederim ve bu olayı kimseye anlatmam.

(3) Hemen ilgili vergi memurlarına ve/veya yetkili otoritelere bu olay ile ilgili bilgi veririm.

Senaryo 2:

Bu senaryo, yukarıda yazılan senaryo 1 aynı ancak vergi kaçırma planlarının, vergi memurları tarafından yakalanma olasıllı̆ınız \%10.

Lütfen bu olay ile ilgili düşüncenizi (yalnızca 1 seçenek) işaretleyiniz.

(1) 3 yıllık rüşveti kabul ederim ve bu olayı kimseye anlatmam.

(2) Hemen istifa ederim ve bu olayı kimseye anlatmam.

(3) Hemen ilgili vergi memurlarına ve/veya yetkili otoritelere bu olay ile ilgili bilgi veririm.

\section{Senaryo 3:}

Üniversiteyi bitirdiniz ve ilk işinizde altı ay geçirdiniz. Büyük bir üretim firmasında muhasebe asistanısınız. Altı ay sonra, yıllık olarak 400.000 TL'lik bir karın düşük gösterilmesini sağlayan zekice düzenlenmiş bir muhasebe planının işletmenizde var olduğunu fark ediyorsunuz. Ve bu nedenle işletmenin hissedarlarına dönüşüm olması gerektiğinin altında gerçekleştiriliyor. Daha sonra patronunuz ile muhasebe sorumlunuzu yüzleştiriyorsunuz ve patronunuzun bu planın yasal olmadığını kabul ettiğini görüyorsunuz. Patron ve geride kalan üç yönetici, bu miktarı eşit olarak aralarında bölüşüyorlar

(her biri yıllık olarak 100.000 dolar alıyor). Bu planın mükemmel şekilde üstü kapatılmış ve işletmenin dış denetçileri, işletmeniz ile ilgili memnuniyetlerini dile getiriyorlar ve gelecek üç yıllık çalışma döneminde her hangi bir değişiklik yapmaya hiç niyetleri yok. Yani yakalanmanın hiçbir yolu olasılığı yok. Ve siz de bu durumun farkındasınız.

Patronunuz size üç yıl için her bir yılbaşına maaşınızdan oldukça yüksek bir meblağ olarak 80.000 dolar teklif ediyor. Ve siz de biliyorsunuz ki yakalanma intimali hiçbir şekilde yok. 
(1) 3 yıllık rüşveti kabul ederim ve bu olayı kimseye anlatmam.

(2) Hemen istifa ederim ve bu olayı kimseye anlatmam.

(3) Hemen ilgili vergi memurlarına ve/veya yetkili otoritelere bu olay ile ilgili bilgi veririm.

Senaryo 4:

Bu senaryo, yukarıda yazılan senaryo 3 aynı ancak işletmenin karını düşük gösterme planlarının dış denetçiler tarafından yakalanma olasılığınız \%10.

Lütfen bu olay ile ilgili düşüncenizi (yalnızca 1 seçenek) işaretleyiniz.

(1) 3 yıllık rüşveti kabul ederim ve bu olayı kimseye anlatmam.

(2) Hemen istifa ederim ve bu olayı kimseye anlatmam.

(3) Hemen ilgili vergi memurlarına ve/veya yetkili otoritelere bu olay ile ilgili bilgi veririm.

Senaryo 5:

Üniversiteden mezun olmanızı sağlamak için muhasebenin final sınavına hazırlanıyorsunuz. Size önemli bir firmanın muhasebe departmanında iyi bir iş vaat edildi. Tabi bu vaat, sizin muhasebenin final sınavından başarı ile geçmenize bağlı. Sınavdan iki gün önce Arda ile karşılaşıyorsunuz. Arda da sizin bölümünüzden mezun biri ama onunla 3 yıldır hiç karşılaşmadınız. Aslında onunla çok iyi arkadaşsınız ve başkalarından da onun iyi bir arkadaş olduğuna dair sözler duyuyorsunuz. O size neler yaptığınızı soruyor ve siz de ona içinde bulunduğunuz bu durumu anlatıyorsunuz. $O$ da size matbaa ve baskı işleri yapan bir firmada yetkili bir konumda çalıştığını ve sizin okulunuzun sınav sorularını kendi firmasının çoğalttığını anlatıyor. Gerçekten de o sizin muhasebe sınav sorularınızı hatırlayabilir. Ve kendisi size yarına muhasebe sınav sorularının bir kopyasını vermeyi teklif ediyor. Ve hiç kimse bu olayı bilmeyeceği için yakalanma olasılı̆̆ınız hiçbir şekilde yok.

Lütfen bu olay ile ilgili düşüncenizi (yalnızca 1 seçenek) işaretleyiniz.

(1) Arda'nın teklifini kabul ederim ve muhasebe sınav sorularını önceden alırım.

(2) Ona teklifi için teşekkür ederim ama teklifini reddederim.

(3) Ona teklifi için teşekkür ederim ama teklifini reddederim. Ve hemen çalıştığı firmanın yetkililerine Arda'nın size yaptığı bu teklifi anlatırım.

\section{Senaryo 6:}

Bu senaryo, yukarıda anlatılan senaryo 5 aynı ancak sınav sorularının kopyasını firmadan alırken, güvenlik görevlisi tarafından yakalanma ihtimaliniz \%10.

Lütfen bu olay ile ilgili düşüncenizi (yalnızca 1 seçenek) işaretleyiniz.

(1) Arda'nın teklifini kabul ederim ve muhasebe sınav sorularını önceden alırım.

(2) Ona teklifi için teşekkür ederim ama teklifini reddederim.

(3) Ona teklifi için teşekkür ederim ama teklifini reddederim. Ve hemen çalıştığı firmanın yetkililerine Arda'nın size yaptığı bu teklifi anlatırım. 